\title{
Polygalacturonase by Aspergillus Niger Using Seaweed Waste Under Submerged Fermentation: Production, Purification and Characterization
}

\author{
Yaaser Q Almulaiky ${ }^{1,2 *}$, Abdulaziz A Albishri ${ }^{1}$, N M Khalil ${ }^{1,3}$, Yousif Algamal ${ }^{1,4}$, Musab Aldhahri ${ }^{5}$, Sami \\ A Al-Harbi ${ }^{6}$, Hasan A Al-Talhi ${ }^{5}$ and Radhi Alhadi ${ }^{1}$ \\ ${ }^{1}$ Chemistry Department, Faculty of Sciences and Arts, University of Jeddah, Saudi Arabia \\ ${ }^{2}$ Chemistry Department, Faculty of Applied Science, Taiz University, Yemen \\ ${ }^{3}$ Refractories, Ceramics and Building Materials Department, National Research Centre, Egypt \\ ${ }^{4}$ Chemistry Department, Faculty of Science \& Technology, Omdurman Islamic University, Sudan \\ ${ }^{5}$ Department of Biochemistry, Faculty of Science, King Abdulaziz University, Saudi Arabia \\ ${ }^{6}$ Department of Chemistry, University College in Al-Jamoum, Umm Al-Qura University, Saudi Arabia \\ *Corresponding author: Yaaser Q Almulaiky, Chemistry Department, Faculty of Sciences and Arts, University of Jeddah, Saudi \\ Arabia
}

\section{ARTICLE INFO}

Received: 幽 February 07, 2020

Published: 慧 February 19, 2020

Citation: Yaaser Q Almulaiky, Abdulaziz A Albishri, N M Khalil, Yousif Algamal, Musab Aldhahri, Sami A AlHarbi, Hasan A Al-Talhi, Radhi Alhadi. Polygalacturonase by Aspergillus Niger Using Seaweed Waste Under Submerged Fermentation: Production, Purification and Characterization. Biomed J Sci \& Tech Res 25(4)-2020. BJSTR. MS.ID.004249.

\section{ABSTRACT}

Polygalacturonases are important enzymes used in industrial applications that treated plant material like Juice extraction, Textile, Clarification etc. Fungi from genus Aspergillus are one of the most important sources of this enzyme. We production Polygalacturonase by submerged fermentation using seaweed waste. Five PG P1-P5 were differentiated on DEAE-Sepharose column. The homogeneity of PGP2a was identified on Sephacryl S-200 chromatography. PGP2a had a molecular weight of $20 \mathrm{kDa}$ by Sephacryl S-200 and SDS-PAGE. The enzyme had an optimal pH of 6 also the temperature optimal of PGP2a was $40{ }^{\circ} \mathrm{C}$. The thermal stability of PGP2a was detected up to $50{ }^{\circ} \mathrm{C}$ and the enzyme was highly stable till $60{ }^{\circ} \mathrm{C}$ after $30 \mathrm{~min}$ incubation. The $\mathrm{V}_{\text {max }}$ and $\mathrm{K}_{\mathrm{m}}$ values of PGP2a were $4.27 \mathrm{mg} / \mathrm{ml}$ and $1.16 \mu \mathrm{mol} \mathrm{min}^{-1} \mathrm{mg}^{-1}$, respectively. The metal ions except only $\mathrm{Co}^{2+}$ and $\mathrm{Hg}^{2+}$ was found to enhance the PGP2a activity.

Keywords: Polygalacturonase; Purification; Aspergillus Niger; Seaweed Waste

\section{Introduction}

Polygalacturonases (PGs) are natural enzymes that are produced by several organisms, such as plants [1-2], bacteria [3-4] and fungi [5-7]. These proteins belong to a large group of pectinases, which synergistically mediate the complete decomposition of pectin substances that are abundantly present in plant tissues, primarily in fruit. Polygalacturonase are pectin-degrading proteins that are classified as exo-or endo-types based on how pectin-degrading proteins are formed. Exo-PGs [E.C. 3.2.1.67] are produced by many fungi [8-13]. Exo-PG is an enzyme that eventually hydrolyses glycosidic bonds in pectate or other galacturons, yielding the corresponding 1,4- $\alpha$-D-galacturonide and galacturonic acid. on the other hand, Endo-PGs [ EC 3.2.1.15] are developed in cultures of many micro-organisms and plants [14]. Their enzymatic reaction involves random in the middle hydrolysis of 0-glycosyl bonds in 1,4- $\alpha$-D-galactosyluronic bonds in homogalacturonans. Microbial polygalacturonase have proven to be instrumental in reducing viscosity and clarifying the juice [15-18]. In general, both submerged state fermentation $(\mathrm{SmF})$ was effectively used in producing 
polygalacturonase from specific microbial strains [19-21], Using different agro-industrial by-products such as cotton, sugar beet and coffee, apple pulps, lemon peels, oranges and tomatoes, apple and citrus fruits, sugarcane bagasse, wheat bran, etc., [22-24]. The present study is the first report on using seaweed waste as media for production enzyme from Aspergillus niger. In this manuscript we describe the production, purification and characterization of polygalacturonase by Aspergillus niger using seaweed waste and its application in fruit juice clarification.

\section{Materials and Methods}

\section{Chemicals}

All the chemicals used for the analytical and laboratory grades were procured from Sigma-Aldrich.

\section{Microorganism and Culture Conditions}

The obtained Aspergillus niger (NRC, Cairo, Egypt), kept on potato dextrose agar and slants were grown at $28^{\circ} \mathrm{C}$ for seven days and kept at $4{ }^{\circ} \mathrm{C}$.

\section{Inoculum Medium}

The inoculum medium used for of $\mathrm{A}$. niger preparation contained (g/l): $\mathrm{MgSO}_{4} .7 \mathrm{H}_{2} 0$, 4.2; Urea, 4.2; $\mathrm{KH}_{2} \mathrm{PO}_{4}, 28 ; \mathrm{FeSO}_{4}$. $7 \mathrm{H}_{2}$ 0, 0.07; (NH4) $\mathrm{SO}_{4}, 19.6$; $\mathrm{CoCl}_{2}, 4.2 ; \mathrm{ZnSO}_{4} 7 \mathrm{H}_{2} 0,0.019$; $\mathrm{CaC1}_{2}$, $0.028 ; \mathrm{MnSO}_{4} .7 \mathrm{H}_{2} 0,0.021$; glucose, 15 ; and yeast extract, 7; pH 5.0 . The media was sterilized $15 \mathrm{~min}$ at $121^{\circ} \mathrm{C}$ pressure by autoclaving. Incubation and shake at $30{ }^{\circ} \mathrm{C}$ for two days in shaking incubator with speed rotation at $150 \mathrm{rpm}$ prior to the production medium [25].

\section{Submerged Fermentation (SmF)}

$\mathrm{SmF}$ was conducted to assess the impact of numerous physical and chemical parameters needed for optimum enzyme saccharification content and production by A. Niger. Sterilization of agricultural waste and then incubated at $121^{\circ} \mathrm{C}$ for $20 \mathrm{~min}$ and 1.2 atm. $5 \mathrm{~g}$ of sterilized agricultural waste, $5 \times 10^{5}$ spores $/ \mathrm{g}$ and adequate water (50\%) were added to $100 \mathrm{ml}$ of Erlenmeyer flask. Every test is in 3 sets. Crude enzyme was extracted for $10 \mathrm{~min}$ at $12000 \mathrm{rpm}$ and the supernatant was designated as a crude extract.

\section{Purification of Polygalacturonase}

Extracts from Aspergillus niger are mounted on a DEAESepharose column balanced with buffer (20 mM Tris-HCl pH 7.2). The enzyme was eluted in the same buffer with a stepwise gradient of 0.0 to $0.3 \mathrm{M} \mathrm{NaCl}$. Fractions in $3 \mathrm{ml}$ of volume at a flow rate of 30 $\mathrm{ml} / \mathrm{h}$ were collected. The eluted fractions were checked for protein at $280 \mathrm{~nm}$ and enzyme activity tested. There were pooled protein fractions with enzyme activity. The most active polygalacturonase (P2) has been concentrated by solid sucrose dialysis and loaded on Sephacryl S-200 column, previously balanced by $20 \mathrm{mM}$ tris- $\mathrm{HCl}$ buffer, pH 7.2 and obtained at a rate of flow $30 \mathrm{ml} / \mathrm{h}$ and fractions of $3 \mathrm{ml}$.

\section{Polygalacturonase Assay}

PG activity was assayed using Polygalacturonic Acid (PGA) as substrate as described [26]. The activity for PGA has been established through the formation of reduction groups [27]. The reaction mixture $(0.5 \mathrm{ml})$ included 2\% PGA, a pH 5.5 buffer of 0.05 $\mathrm{M}$ sod. acetate and an appropriate amount of enzyme. At $37^{\circ} \mathrm{C}$ for $1 \mathrm{~h}$, analysis was done. Then a reagent of $0.5 \mathrm{ml}$ of DNS was applied, heated for 10 minutes in water bath. The absorbance was estimated at $560 \mathrm{~nm}$ after cooling to room temperature. A unit of enzyme activity was specified as the amount of the enzyme that released $1 \mu \mathrm{mol}$ per minute of galacturonic acid under standard test conditions.

\section{Protein Determination}

Method of Bradford (1976) was used to determine the protein concentration [28], using BSA as a standard.

\section{Molecular Weight Determination}

The method of determination molecular weight using gel filtration technique and the subunit molecular weight of the pure enzyme was determined according to the method mentioned by Laemmli [29].

\section{Characterization of Polygalacturonase}

Optimum pH: Polygalacturonase activity was assessed at different $\mathrm{pHs}$, with various buffers, sodium acetate ( $\mathrm{pH}$ 4.0-6.0) and Tris- $\mathrm{HCl}$ (6.5-9) at $50 \mathrm{mM}$ levels. The maximum activity was $100 \%$ and relative activity was compared with different $\mathrm{pH}$ values.

Kinetic Parameters: $\mathrm{K}_{\mathrm{m}}$ and $\mathrm{V}_{\text {max }}$ values were determined from Lineweaver-Burk plots using 3-7 mg / ml polygalacturonic acid.

Optimum Temperature: The activity of polygalacturonase was determined at a $30-80{ }^{\circ} \mathrm{C}$ temperature range. Maximum activity was taken as $100 \%$ and relative activity plotted against different temperatures.

Thermal Stability: The enzyme was incubated at $30-80^{\circ} \mathrm{C}$ for 30 min before addition to the substrate.

Effect of Metal Ions: The enzyme was implanted for 30 minutes $2 \mathrm{mM} \mathrm{Pb}{ }^{2+}, \mathrm{Hg}^{2+}, \mathrm{Co}^{2+}, \mathrm{Zn}^{2+}, \mathrm{Ni}^{2+}, \mathrm{Cu}^{2+}$ and $\mathrm{Ca}^{2+}$ prior to substrate addition. The enzyme activity without metal ions was taken as $100 \%$ and in the presence of metal ions, relative activity (\%) was determined.

Clarification of Orange Juice: Fruit juice clarity was studied using method of [30]. $100 \mu \mathrm{L}$ of polygalacturonase was applied to $2 \mathrm{~mL}$ of apple juice, incubated at $37^{\circ} \mathrm{C}$ in a water bath for 30,60 and $120 \mathrm{~min}$. Holding the reaction mixture in water bath for $5 \mathrm{~min}$ prevented the reaction. Centrifuged at $3000 \mathrm{rpm}$ for $5 \mathrm{~min}$. The transmittance (\%) was calculated at $660 \mathrm{~nm}$ for controls containing the same enzyme volume applied just before holding the reaction mixture in water bath. 


\section{Result and Dissection}

Polygalacturonase produced by aspergillum Niger using seaweed waste during submerged fermentation was purified in two steps, involving ion exchange chromatography and gel filtration. Table 1 summarizes the purification process. Five peaks of PG activity (Figure 1), negatively adsorbed fraction and eluted portions with $0.05,0.1,0.2$ and $0.3 \mathrm{M}$ sodium chloride are observed in the elution profile of PG on DEAE-Sepharose and designated as PGP1, P2, P3 P4 and P5. The PGP2 with highest activity was separated on Sephacryl S-200 column to obtain PGP2a (Figure 2) with the highest specific activity 1400 units/mg protein with 10.9 fold. In this study, the purified PGP2a gave a molecular weight of $20 \mathrm{kDa}$ using Sephacryl S-200 column with a single band of protein on SDSPAGE (Figure 3). The molecular masses of PG ranged from 24 to $34 \mathrm{kDa}$ were detected as penicillium viridicatum [31], banana friut [32], Aspergillus awamori [33], penicillium expansum [34]. The purified PGP2a showed maximum activity at pH 6 (Figure 4), similar to the result obtained by Esawy [35]. Acidic $\mathrm{pH}$ optima ranged from 4.5 to 6 were reported for PGase from Aspergillus awamori ( $\mathrm{pH}$ 4.5) [33], Aspergillus niger CFR 305 (pH 4.5) [36], Rice Weevil (pH 5.5) [37]. The optimal temperature of PGP2a activity produced by Aspergillus niger during submerged fermentation in seaweed waste was between $40^{\circ} \mathrm{C}$ (Figure 5). Similarly, optimal activity at $60^{\circ} \mathrm{C}$ was recorded for exo-PG obtained from P. viridicatum RFC3 cultivated on wheat bran and orange bagasse [31], $43^{\circ} \mathrm{C}$ for PG obtained from Penicillium chrysogenum [38], $40^{\circ} \mathrm{C}$ for PG obtained from banana fruit [39]. The purified PGP2 enzyme exhibit thermal stability up to $40^{\circ} \mathrm{C}$. The purified enzyme preserved $50 \%$ of its original activity for $30 \mathrm{~min}$ at $60^{\circ} \mathrm{C}$, while at $80^{\circ} \mathrm{C}$ the activity declined to 9\% (Figure 6). Similar maximum stability has been reported for PG from Aspergillus niger MTCC 478 [40]. Figure 7 demonstrates that the Km and Vmax values for hydrolyzing PGA by the purified PGP2a were $4.27 \mathrm{mg} / \mathrm{ml}$ and $1.16 \mu \mathrm{mol} \mathrm{min}-1 \mathrm{mg}-1$, while $\mathrm{Km} / \mathrm{Vmax}$ was 3.68. Low Km value suggests better affinity to substrate. A PG from A. tubingensis has Km value of $3.2 \mathrm{mg} / \mathrm{mL}$ [41] Many microbial PGs have $\mathrm{km}$ of value between 0.1-5.0 [42-47]. The influence of different metal ions was assessed using $2 \mathrm{mM}$ concentration of each metal ion in the reaction mixture (Table 2). Amongst all metal ions only $\mathrm{Co}^{2+}$ and $\mathrm{Hg}^{2+}$ was found to enhance the PG activity. $\mathrm{Pb}^{2+}, \mathrm{Zn}^{2+}, \mathrm{Ni}^{2+}$, $\mathrm{Cu}^{2+}$ and $\mathrm{Ca}^{2+}$ ions stimulated the enzyme activity to $131 \%, 180 \%$, $141 \%, 119 \%$ and $123 \%$, respectively. Activity loss can be caused by destabilization of the enzyme as a result of loss of surface chargecharge interaction. Such results are consistent with the enzyme activity actions of other PGs. For example, PG from Aspergillus niger MTCC 478 lost $20 \%$ and $4 \%$ in activity in the presence of $\mathrm{Co}^{+2}$ and $\mathrm{Hg}^{+2}$ [39], exopolygalacturonase from a strain of Bacillus gained $60 \%, 36 \%, 30 \%, 18 \%$ and $16 \%$ when $\mathrm{Mg}^{+2}, \mathrm{Mn}^{+2}, \mathrm{~Pb}^{2+}, \mathrm{Ca}^{+2}$ and $\mathrm{Fe}^{+3}$ were added to the reaction [48].

Table 1: Purification scheme for PG.

\begin{tabular}{|c|c|c|c|c|c|}
\hline \multirow{2}{*}{ Step } & Total protein & \multirow{2}{*}{ Total activity (units)* } & S.A* & \multirow{2}{*}{ Fold purification } & \multirow{2}{*}{$\begin{array}{c}\text { Recovery } \\
\% \\
\end{array}$} \\
\hline & (mg) & & (units/mg protein) & & \\
\hline $\begin{array}{l}\text { Crude extract } \\
\text { Chromatography }\end{array}$ & 20 & 2580 & 129 & 1 & 100 \\
\hline on DEAE- Sepharose & 2 & 191 & 95.5 & & \\
\hline $0.0 \mathrm{M} \mathrm{NaCl}(\mathrm{P} 1)$ & 2.2 & 412 & 187 & 0.74 & 7.4 \\
\hline $0.05 \mathrm{M} \mathrm{NaCl}(\mathrm{P} 2)$ & 1.7 & 113 & 66 & 1.45 & 16 \\
\hline $0.1 \mathrm{M} \mathrm{NaCl}(\mathrm{P} 3)$ & 1.6 & 89 & 55.6 & 0.5 & 4 \\
\hline $0.2 \mathrm{M} \mathrm{NaCl}(\mathrm{P} 4)$ & 1.9 & 89 & 47 & 0.4 & 3 \\
\hline $0.3 \mathrm{M} \mathrm{NaCl}(\mathrm{P} 5)$ & & & & 0.36 & 3 \\
\hline \multicolumn{6}{|l|}{ Gel filtration } \\
\hline \multicolumn{6}{|l|}{ on Sephacryl S-200 } \\
\hline PGP2a & 0.08 & 112 & 1400 & 10.9 & 4.3 \\
\hline
\end{tabular}

Note: *One unit of peroxidase activity is defined as the amount of enzyme which increases the O.D. 1.0 per min under standard assay conditions.

Table 2: Effect of metal ions on the activity of purified PGP2a.

\begin{tabular}{|c|c|}
\hline Metals (2mM) & \% Relative activity \\
\hline Control & 100 \\
\hline $\mathrm{Pb} 2+$ & 131 \\
\hline $\mathrm{Hg} 2+$ & 66 \\
\hline $\mathrm{Co} 2+$ & 75 \\
\hline $\mathrm{Zn} 2+$ & 180 \\
\hline $\mathrm{Ni2}+$ & 141 \\
\hline $\mathrm{Cu} 2+$ & 119 \\
\hline $\mathrm{Ca} 2+$ & 123 \\
\hline
\end{tabular}




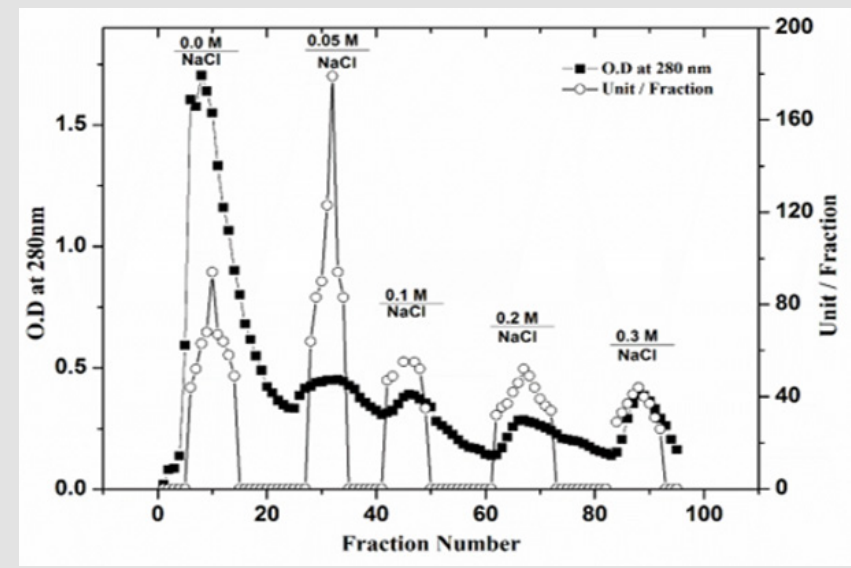

Figure 1: A typical elution profile for the chromatography of PG on DEAE-Sepharose column $(10 \times 1.6 \mathrm{~cm}$ i.d. $)$ previously equilibrated with $20 \mathrm{mM}$ Tris- $\mathrm{HCl}$ buffer, $\mathrm{pH}$ 7.2 at a flow rate of $60 \mathrm{ml} / \mathrm{h}$ and $3 \mathrm{ml}$ fractions.

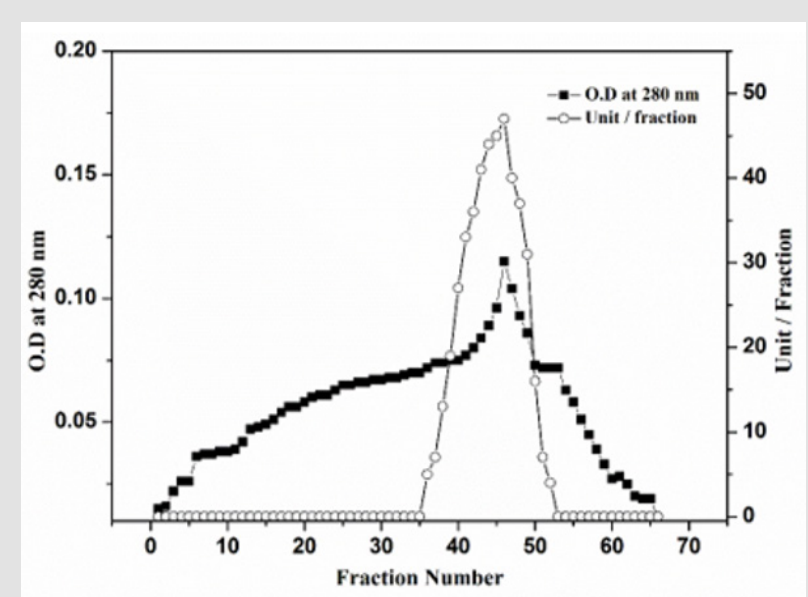

Figure 2: Gel filtration of PGaP2a DEAE-Sepharose fractions on Sephacryl S-200 column $(90 \times 1.6 \mathrm{~cm}$ i.d. $)$. The column was equilibrated with $20 \mathrm{mM}$ Tris- $\mathrm{HCl}$ buffer, $\mathrm{pH}$ 7.2 at a flow rate of $30 \mathrm{ml} / \mathrm{h}$ and $3 \mathrm{ml}$ fractions.

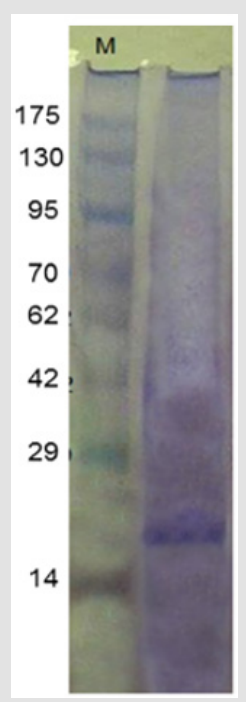

Figure 3: SDS-PAGE for homogeneity and molecular weight determination of PGP2a.

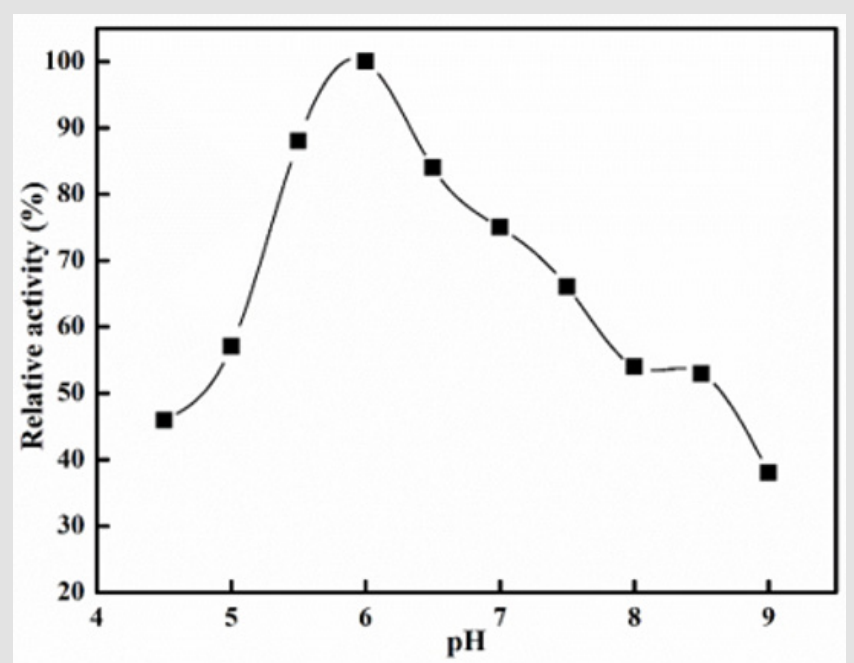

Figure 4: Optimum pH of PGP2a.

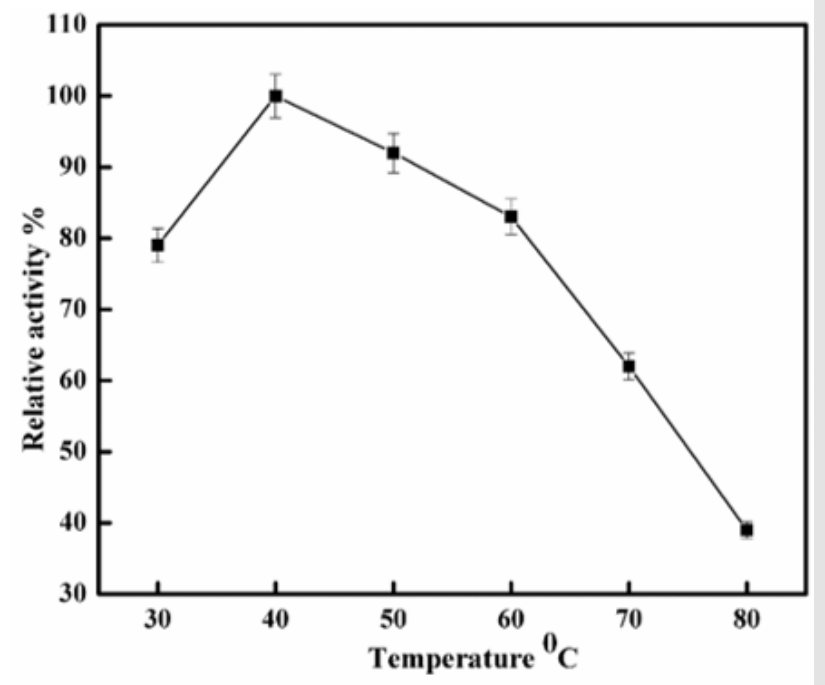

Figure 5: Temperature optimum of PGP2a.

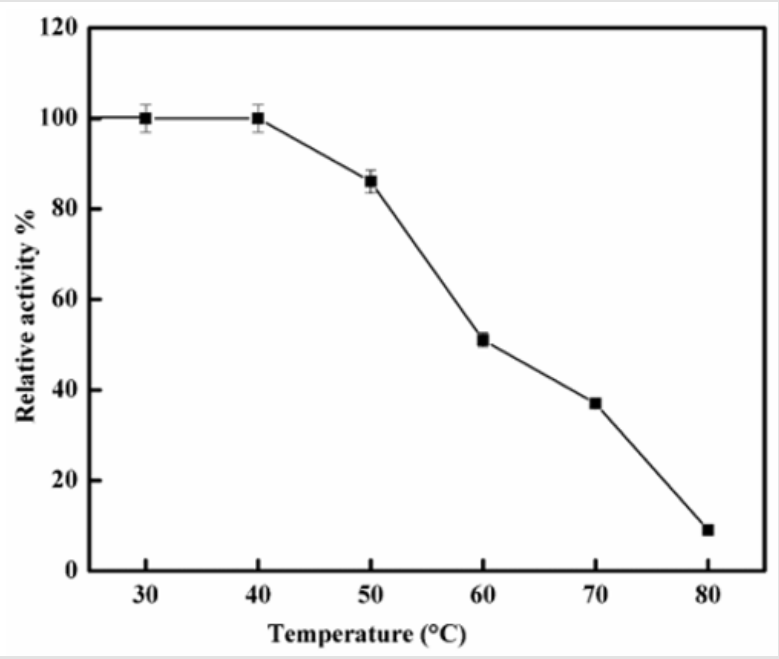

Figure 6: The thermal stability of PGP2a. 


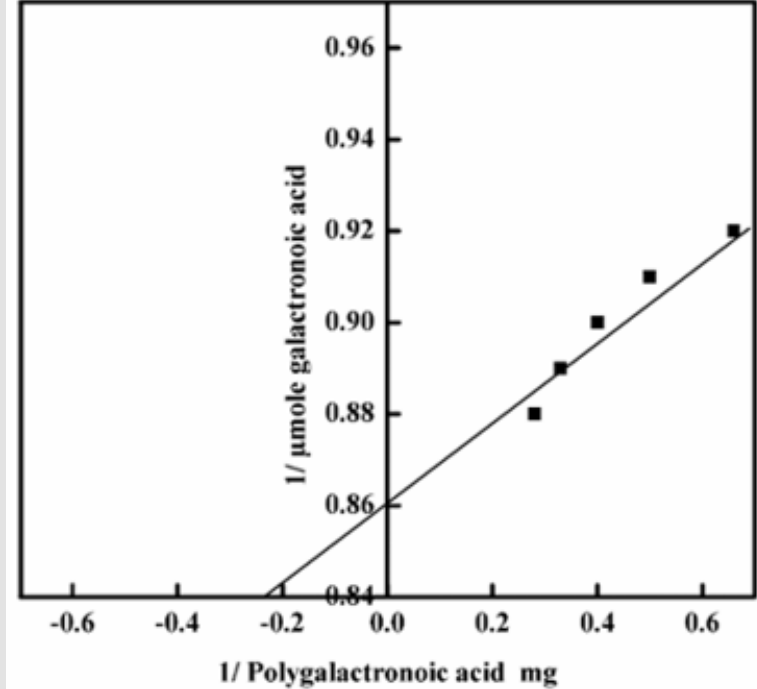

Figure 7: Kinetics parameters (Km) of purified PGP2a.

\section{Application of Purified PG in Clarification of Fruit Juice}

Microbial polygalacturonases are generally a significant group of potentially applicable enzymes across different industries such as textile, wine, paper, and food industries [49]. The application of purified PGP2a on orange juice obtained from the local market was studied in clarifying the fruit juice. The clarification of fruit juice was examined using the method [30]. The results of these tests are shown in Figure 8 in which can be seen that the transmittance increased by $16 \%, 33 \%$ and $42 \%$ When incubated for 30,60 and 120 min respectively, with regard to monitoring that the same enzyme amount was applied Just before a mixture of reactions was placed in water bath. The transmission of the juice treated improved by the elimination in particular of pectin of colloidal and suspended particles. Since pectin is present, colloid formation in the fruit juice industry is a major challenge, which reduces the market value of juices. In fruit juices, pectinase degrades pectin in fruit juices, reducing viscosity and cluster formation. The juice is therefore simpler and more intense in taste and colour [50-51]. Fruit juice clarity can be due to the enzyme's biochemical composition. Polygalacturonase had optimum $\mathrm{pH}$ at 6.0 and pH stability of 4.5 to 8.5. Therefore, acidic polygalacturonase can be used as a potential candidate for clarifying fruit juice. Several Aspergillus carbonarius and Achaetomium sp Xz8 polygalacturonases has been shown to be able to improve the yield and clarity of the juice [52] and reducing the papaya juice viscosity [53]. Polygalacturonase made by A. niger with banana peel as a substratum was used to clarify banana juice [54]. The use of Neosartorya fisheri polygalacturonases in clarification of apple and strawberry juice was also reported [55]. An acidic A. Niger PG was also used for guava juice clarification [56]. Penicillium oxalicum endopolygalacturonase improved the light transmission of papaya pulp by $29.5 \%$ [57].

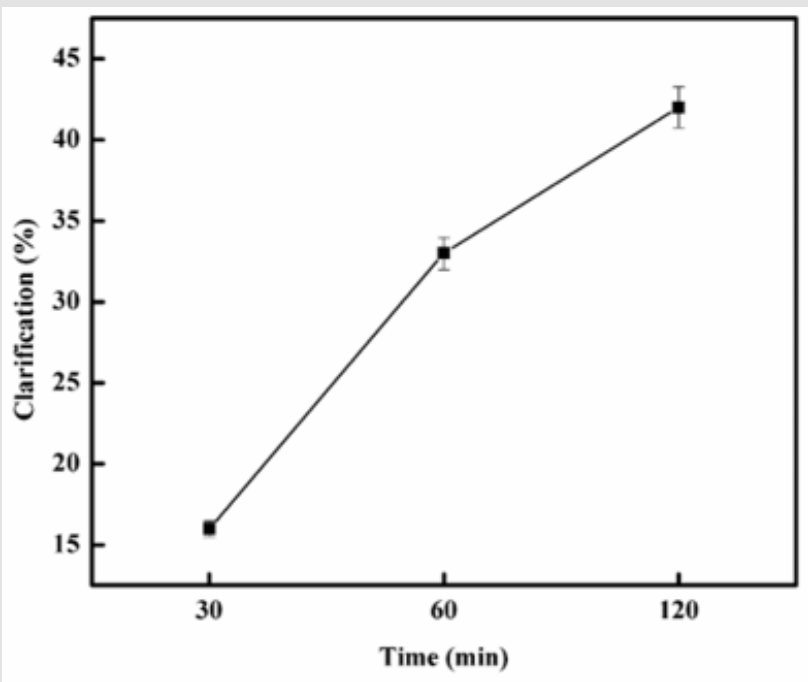

Figure 8: Clarification of orange juices, using 10 units (U) of purified enzyme (PGP2a) activity per $\mathrm{mL}$ of juice.

\section{Conclusion}

Polygalacturonase from Aspergillus niger was produced by submerged fermentation using seaweed waste was purified simply by DEAE-Sepharose and Sephacryl S-200 columns chromatography. A relatively molecular weight PGP2a of $20 \mathrm{kDa}$ with $\mathrm{pH}$ and temperature optimum of 6 and $40{ }^{\circ} \mathrm{C}$ was observed. The Km and Vmax value of purified PG was found to be $4.27 \mathrm{mg} /$ $\mathrm{ml}$ and $1.16 \mu \mathrm{mol} \mathrm{min}{ }^{-1} \mathrm{mg}^{-1}$, respectively, several metal ions under studies found to enhance the PG activity. The potential of purified PGP2a in clarification of orange juice was illustrated owing to its acidic nature.

\section{References}

1. Bird CR, Smith CJS, Ray JA, Moureau P, Bevan MW, et al. (1988) The tomato polygalac-turonase gene and ripening-specific expression in transgenic plants. Plant Mol Biol 11(5): 651-662.

2. Hadfield KA, Bennett AB (1998) Polygalacturonases: Many genes in search of a function. Plant Physiol 117(2): 337-343.

3. Jayani RS, Shukla SK, Gupta R (2010) Screening of bacterial strains for polygalacturonase activity: Its production by Bacillus sphaericus (MTCC 7542). Enzyme Res 2010: 1-5.

4. Tariq A, Latif Z (2012) Isolation and biochemical characterization of bacterial isolates producing different levels of polygalacturonases from various sources. Afr J Microbiol Res 6(45): 7259-7264.

5. Martins ES, Leite RSR, Silva R, Gomes E (2013) Purification and properties of polygalacturonase produced by thermophilic fungus Thermoascus aurantiacus CBMAI-756 on solid-state fermentation. Enzyme Res.

6. Anuradha K, Naga Padma P, Venkateshwar S, Reddy G (2014) Selection of nutrients for polygalacturonase production by Aspergillus awamori MTCC 9166 using Plackett-Burman design. Indian J Biotechnology 13: 502-507.

7. Cheng Z, Chen D, Lu B, Wei Y, Xian L, et al. (2016) A novel acid-stable endo-polygalacturonase from Penicillium oxalicum CZ1028: Purification, characterization and application in the beverage industry. J Microbiol Biotechnol 26(6): 989-998. 
8. Heinrichova' K, Rexova'-Benkova' L (1976) Purification and characterization of an extracellular exo-D-galacturonase of Aspergillus niger. Biochim Biophys Acta 422(2): 349-356.

9. Maceira FIG, Pietro AD, Roncero MIG (1997) Purification and characterization of a novel exopolygalacturonase from Fusarium oxysporum f. sp. lycopersici. FEMS Microbiol Lett 154(1): 37-43.

10. Johnston DJ, Williamson B (1992) Purification and characterization of four polygalacturonases from Botrytis cinerea. Mycol Res 96(5): 343349.

11. Nozaki K, Miyairi K, Hozumi S, Fukui Y, Okuno T (1997) Novel exopolygalacturonases produced by Alternaria mali. Biosci Biotechnol Biochem 61(1): 75-80.

12. Riou C, Freyssinet G, Fevre M (1992) Purification and characterization of extracellular pectinolytic enzymes produced by Sclerotinia sclerotiorum. Appl Environ Microbiol 58(2): 578-583.

13. Kumar SS, Palanivelu P (1999) Purification and characterization of an extracellular polygalacturonase from the thermophilic fungus, Thermomyces lanuginosus. World J Microbiol Biotechnol 15(5): 643646.

14. Rombouts FM, Pilnik W (1980) Pectic enzymes. In: Rose AH (Editor). Economic Microbiology. volume 5. Academic Press, London, pp. 227282.

15. Kashyap DR, Vohra PK, Chopra S, Tewari R (2001) Applications of Pectinases in commercial sector: A review. Biores Technol 77(3): 215227.

16. Kant S, Vohra A, Gupta R (2013) Purification and physicochemical properties of polygalacturonase from Aspergillus niger MTCC 3323. Prot Exp Purif 87(1): 11-16.

17. Barman S, Sit N, Badwaik LS, Deka SC (2015) Pectinase production by Aspergillus niger using banana (Musa balbisiana) peel as substrate and its effect on clarification of banana juice. J Food Sci Technol 52(6): 3579 3589.

18. Amin F, Bhatti HN, Bilal M, Asgher M (2017) improvement of activity, thermostability and fruit juice clarification characteristics of fungal Polygalacturonase. Int J Biol Macromol 95: 974-984.

19. Silva D, Martins ES, Silva R, Gomes E (2002) Pectinase production by Penicillium viridicatum RFC3 by solid state fermentation using agricultural wastes and agro-industrial byproducts. $\mathrm{Br} \mathrm{J}$ Microbiol 33(4): 318-324.

20. Pedrolli DB, Carmona EC (2009) Pectin lyase from Aspergillus giganteus: comparative study of productivity of submerged fermentation on citrus pectin and orange waste. Prikl Biokhim Mikrobiol 45(6): 677-683.

21. Dinu D, Nechifor MT, Stoian G, Costache M, Dinischiotu A (2007) Enzymes with new biochemical properties in the pectinolytic complex produced by Aspergillus niger MIUG 16. J Biotechnol 131(2): 128-137.

22. Yadav S, Shastri NV (2007) Purification and properties of an extracellular pectin lyase produced by the strain of Penicillium oxalicum in solid-state fermentation. Indian J Biochem Biophys 44(4): 247-251.

23. Lara-Marquez A, Zavela-Paramo MG, Lopez-Romero E, Horacio CC (2011) Biotechnological potential of pectinolytic complexes of fungi. Biotechnol Lett 33(5): 859-868.

24. Yadav S, Dubey AK, Anand G, Kumar R, Yadav D (2014) Purification and biochemical characterization of an alkaline pectin lyase from Fusarium decemcellulare MTCC 2079 suitable for Crotolaria juncea fiber retting. J Basic Microbiol 54: S161-S169.

25. Duenas R, Tengerdy RP, Correa MG (1995) Cellulase production by mixed fungi in solid-substrate fermentation of bagasse. World J Microbiol Biotechnol 11(3): 333-337.

26. Contreras-Esquivel JC, Hours RA, Voget CE, Mignone CF (1999) Aspergillus kawachii produces an acidic pectin releasing enzyme activity. J Biosci Bioeng 88(1): 48-52.

27. Miller GL (1959) Use of dinitrosalicylic acid reagent for determination of reducing sugar. Anal Chem 31(3): 426-429.
28. Bradford MM (1976) A rapid and sensitive method for the quantitation of microgram quantities of protein using the principle of protein-dye binding. Anal Biochem 72: 248-254.

29. Laemmli UK (1970) Cleavage of structural protein during the assembly of the head of bacterio phase T4. Nature 227(5259): 680-885.

30. Ishii S, Yokotsuka $\mathrm{T}$ (1972) Clarification of fruit juice by pectin transeliminase. J Agric Food Chem 20(4): 787-791.

31. Denis S, Martins ES, Leite RS R, Da Silva R, Ferreira V, et al. (2007) Purification and characterization of an Polygalacturonase produced by Penicillium viridicatum RFC3 in solid-state fermentation. Process Biochemistry 42(8): 1237-1243.

32. Neelam P, Mishra S, Sanwal GG (2000) Purification and characterization of polygalacturonase from banana fruit. Phytochemistry 54(2): 147-152.

33. Bhanja DT, Adak S, Bhattacharya P, Banerjee R (2014) Purification of polygalacturonase from Aspergillus awamori Nakazawa MTCC 6652 and its application in apple juice clarification. LWT-Food Science and Technology 59(1): 591-595.

34. Chenglin Y, Conway WS, Sams CE (1996) Purification and characterization of a polygalacturonase produced by Penicillium expansum in apple fruit. Phytopathology 86(11): 1160-1166.

35. Esawy MA, Gamal AA, Kamel Z, Ismail AM, Abdel-Fattah AF (2013) Evaluation of free and immobilized Aspergillus niger NRC1ami pectinase applicable in industrial processes. Carbohydrate polymers 92(2): 14631469.

36. Pushpa MS, Naidu MM (2011) Improvement of robusta coffee fermentation with microbial enzymes. European journal of applied sciences 3(4): 130-139.

37. Zhicheng S, Reese RC, Reeck GR (1996) Purification and characterization of polygalacturonase from the rice weevil, Sitophilus oryzae (Coleoptera: Curculionidae). Insect Biochemistry and Molecular Biology 26(5): 427 433.

38.Zaslona H, Trusek-Holownia A (2015) Enhanced production of polygalacturonase in solid-state fermentation: selection of the process conditions, isolation and partial characterization of the enzyme. Acta Biochimica Polonica 62(4): 651-657.

39. Neelam P; Sanjay M, Sanwal GG (2000) Purification and characterization of polygalacturonase from banana fruit. Phytochemistry 54(2): 147-152.

40. Anand G, Yadav S, Yadav D (2017) Production, purification and biochemical characterization of an Polygalacturonase from Aspergillus niger MTCC 478 suitable for clarification of orange juice. 3 Biotech 7(2): 122.

41. Kester HCM, Kusters-Van Someren MA, Muller Y, Visser J (1996) Primary structure and characterization of an exopolygalacturonase from Aspergillus tubingensis. Eur J Biochem 240(3): 238-246.

42. Zhang J, Bruton BD, Biles CL (1999) Fusarium solani endopolygalacturonase from decayed muskmelon fruit: purification and characterization. Physiol Mol Plant Pathol 54(5-6): 171-186.

43. Niture SK, Pant A, Kumar AR (2001) Active site characterization of the single endo-polygalacturonase produced by Fusarium moniliforme NCIM 1276. Eur J Biochem 268(3): 832-840.

44. Singh SA, Rao AGA (2002) A simple fractionation protocol for, and a comprehensive study of the molecular properties of, two major endopolygalacturonases from Aspergillus niger. Biotechnol Appl Biochem 35(2): 115-123.

45. Thakur A, Pahwa R, Singh S, Gupta R (2010) Production, purification, and characterization of polygalacturonase from Mucor circinelloides ITCC 6025. Enzyme Res.

46. Martins ES, Leite RSR, Silva R, Gomes E (2013) Purification and properties of polygalacturonase produced by thermophilic fungus Thermoascus aurantiacus CBMAI-756 on solid-state fermentation. Enzyme Res.

47. Chen Y, Sun D, Zhou Y, Liu L, Han W, et al. (2014) Cloning, expression and characterization of a novel thermophilic polygalacturonase from Caldicellulosiruptor bescii DSM 6725. Int J Mol Sci 15(4): 5717-5729. 
48. Kobayashi T, Higaki N, Suzumatsu A, Sawada K, Hagihara H, et al (2001) Purification and properties of a high-molecular-weight, alkaline exopolygalacturonase from a strain of Bacillus. Enzyme and Microbial Technology 29(1): 70-75.

49. Garg G, Singh A, Kaur A, Singh R, Kaur J, et al. (2016) Microbial Pectinases: an ecofriendly tool of nature for industries. 3 Biotech 6(1): 47.

50. Liew Abdullah AG, Sulaiman NM, Aroua MK, Megat Mohd Noor M] (2007) Response surface optimization of conditions for clarification of carambola fruit juice using a commercial enzyme. J Food Eng 81(1): 6571.

51. Kaur G, Kumar S, Satyanarayana T (2004) Production, characterization and application of a thermostable polygalacturonase of a thermophilic molud Sporotrichum thermophile. Apinis Bioresour Technol 94(3): 239243.

52. Nakkeeran E, Umesh-Kumar S, Subramanian R (2011) Aspergillus carbonariuspolygalacturonases purified by integrated membrane process and affinity precipitation for apple juice production. Biores Technol 102(3): 3293-3297.

\section{ISSN: 2574-1241}

DOI: 10.26717/BJSTR.2020.25.004249

Yaaser Q Almulaiky. Biomed J Sci \& Tech Res

(c) (P) This work is licensed under Creative

Submission Link: https://biomedres.us/submit-manuscript.php
53. Tu T, Luo H, Meng K, Cheng Y, Ma R, et al. (2015) Improvement in thermostability of an Achaetomium sp. Strain Xz8 endopolygalacturonase via the optimization of charge-charge interactions. Appl Environ Micrbiol 81(19): 6938-6944.

54. Barman S, Sit N, Badwaik LS, Deka SC (2015) Pectinase production by Aspergillus nigerusing banana (Musa balbisiana) peel as substrate and its effect on clarification of banana juice. J Food Sci Technol 52(6): 35793589.

55. Pan X, Li K, Ma R, Shi P, Huang H, etal. (2015) Biochemical characterization of three distinct polygalacturonases from Neosartorya fischeri P1. Food Chem 188: 569-575.

56. Kant S, Vohra A, Gupta R (2013) Purification and physicochemical properties of polygalacturonase from Aspergillus niger MTCC 3323. Prot Exp Purif 87(1): 11-16

57. Cheng Z, Chen D, Lu B, Wei Y, Xian L, et al. (2016) A novel acid-stable endo-polygalacturonase from Penicillium oxalicum CZ1028: Purification, characterization and application in the beverage industry. J Microbiol Biotechnol 26(6): 989-998.

$\begin{array}{ll}\text { BIOMEDICAL } & \text { Assets of Publishing with us } \\ \text { RESEARCHES } & \text { - Global archiving of articles } \\ \text { - Immediate, unrestricted online access } & \text { - Rigorous Peer Review Process } \\ & \text { - Authors Retain Copyrights } \\ \end{array}$

